\title{
High polarity extracts obtained from llex guayusa Loes. leaves, exhibit antioxidant capacity
}

\author{
Extractos de alta polaridad obtenidos a partir de las hojas \\ de llex guayusa Loes. exhiben capacidad antioxidante
}

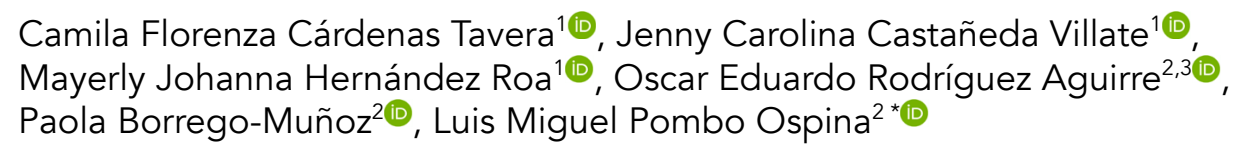

JOURNAL VITAE

School of Pharmaceutical and Food Sciences ISSN 0121-4004 | ISSNe 2145-2660 University of Antioquia Medellin, Colombia

Filliations

${ }^{1} \mathrm{MD} /$ Especialista en Terapéuticas Alternativas y Farmacología Vegetal.

Escuela de Medicina, Fundación Universitaria Juan N. Corpas, 111196 Bogotá, Colombia.

${ }^{2}$ Investigador. Grupo de Investigación GIFTA, Escuela de Medicina. Fundación

Universitaria Juan N. Corpas, 111196 , Bogotá, Colombia.

${ }^{3}$ Profesor. Facultad de Ingeniería, Universidad del Bosque,110121, Bogotá, Colombia.

*Corresponding Luis Miguel Pombo Ospina miguel.pombo@juanncorpas.edu.co

Received: 23 August 2021 Accepted: 04 January 2022 Published: 09 February 2022

\begin{abstract}
Background: Ilex guayusa Loes. belongs to the family Aquifoliaceae. It is an evergreen tree native to the Amazon region. According to traditional uses, it is used as a diaphoretic, narcotic, purgative, among other uses. Objective: To evaluate the antioxidant capacity, quantify phenols and total flavonoids of extracts obtained from llex guayusa leaves. Methods: Total ethanolic extract was obtained using Soxhlet-type equipment, with subsequent liquid/liquid fractionation with solvents of different polarities (petroleum ether, dichloromethane, and ethyl acetate); were reacted with 2,2-diphenyl-1-picrylhydrazyl (DPPH ${ }^{\circ}$ ) and 2,2'-azino-bis3-ethylbenzothiazoline-6-sulfonic acid $\left(\mathrm{ABTS}^{\circ+}\right)$, determining the inhibitory concentration 50 $\left(\mathrm{IC}_{50}\right)$ and relative antioxidant activity $(\% A A R)$, with subsequent statistical analysis (ANOVA and Tukey's post-hoc). Total phenols and flavonoids were quantified using the Folin-Ciocalteu method and complex formation with $\mathrm{AlCl}_{3}$, respectively. Results: The ethanolic extract of leaves showed the highest antioxidant activity in both the DPPH ${ }^{\bullet}$ and $\mathrm{ABTS}^{\bullet+}$ methods with $\mathrm{IC}_{50}$ values of 4.58 and 3.82 ppm, respectively. Conclusions: According to the results obtained in this study, it was possible to corroborate that the ethanolic extract (EE) obtained from the leaves of $I$. guayusa showed the highest antioxidant capacity, by the DPPH ${ }^{\bullet}$ and $\mathrm{ABTS}^{\bullet+}$ methods. Additionally, it was possible to relate this capacity to the high flavonoids content present in this extract. Based on the above and accompanied by future studies, the llex guayusa species could be proposed as an important source of antioxidant compounds with possible application in medicine and the food industry.
\end{abstract}

Keywords: Ilex guayusa Loes, Antioxidant capacity, DPPH, ABTS, Phenolic compounds. 


\section{RESUMEN}

Antecedentes: Ilex guayusa Loes. pertenece a la familia Aquifoliaceae. Es un árbol perenne, nativo de la región amazónica. De acuerdo con los usos tradicionales es empleada como diaforético, narcótico, purgativo, entre otros usos. Objetivo: Evaluar la capacidad antioxidante, cuantificar fenoles y flavonoides totales de extractos obtenidos a partir de las hojas de Ilex guayusa. Métodos: El extracto etanólico total se obtuvo mediante un equipo tipo "Soxhlet", con posterior fraccionamiento líquido/ líquido con solventes de diferentes polaridades (éter de petróleo, diclorometano y acetato de etilo); se hicieron reaccionar con 2,2-difenil-1-picrilhidracilo (DPPH) y ácido 2,2'-azino-bis-3-etilbenzotiazolin-6-sulfónico (ABTS ${ }^{*+}$ ), determinando la concentración inhibitoria $50\left(\mathrm{IC}_{50}\right)$ y la actividad antioxidante relativa (\%AAR), con posterior análisis estadístico (ANOVA y post-hoc de Tukey). Los fenoles y flavonoides totales se cuantificaron con el método de Folin-Ciocalteu y el de formación de complejos con $\mathrm{AlCl}_{3}$, respectivamente. Resultados: El extracto etanólico de las hojas fue el que presentó mayor actividad antioxidante tanto en el método $\mathrm{DPPH}^{\bullet}$ como en el $\mathrm{ABTS}^{*+}$ con valores de $\mathrm{IC}_{50}$ de 4,58 y 3,82 ppm, respectivamente. Conclusiones: De acuerdo con los resultados obtenidos en este estudio, se pudo corroborar que el extracto etanólico obtenido de las hojas de I. guayusa mostró la mayor capacidad antioxidante, por los métodos DPPH y ABTS ${ }^{*+}$. Adicionalmente, se pudo relacionar esta capacidad con el alto contenido de flavonoides presentes en este extracto. Con base en lo anterior y acompañado de futuros estudios, la especie I. guayusa podría proponerse como una importante fuente de compuestos antioxidantes con posible aplicación en los campos de la medicina y la industria alimentaria.

Palabras clave: Ilex guayusa Loes, Capacidad antioxidante, DPPH, ABTS, Compuestos fenólicos.

\section{INTRODUCTION}

Ilex guayusa Loes (Guayusa) belongs to the Aquifoliaceae family; it is a native Amazonian shrub that reaches 6 to $10 \mathrm{~m}$ in height, found in countries such as Ecuador, Bolivia, Peru, and Colombia (1). It is distributed in the Amazon foothills, in the Andean mountains at an altitude of 200 to 2,000 m.a.s.l. (2).

Several studies have reported its traditional use such as rituals by the inhabitants of the Amazonian territory of Ecuador due to its stimulating and healing properties $(3,4)$. Currently, Guayusa has gained relevance in Ecuador and in the world for its health-promoting properties and especially for its high caffeine content, which could explain the development of nutraceuticals, dietary supplements, and antioxidants (5). Guayusa leaves have been reported to be used by many Amazonian communities as a diuretic, diaphoretic, emetic, hypnotic, narcotic, stimulant, and purgative (6).

In recent years, an important number of studies have been conducted on the chemical composition of I. guayusa, considering this species as an interesting source of secondary metabolites, such as pentacyclic triterpenes, xanthines, flavonoids, phenolic compounds, carotenoids, saponins, and derivatives of chlorogenic acid (7-9).

The bioactivity of $I$. guayusa extracts could be strongly related to phenolic compounds and flavonoids (2). These compounds are well known because they have different biological activities, such as their high antioxidant activity, anti-inflammatory agents, and importance in inhibiting various proinflammatory mediators. They have been used to manage metabolic syndromes, cancers, cognitive disorders, and the immune system (10).

Due to these antecedents, in recent years, the interest in this type of compounds has increased since epidemiological studies reveal that the consumption of foods and beverages with a high content of phenolic compounds and flavonoids have been associated as protective agents against fatal degenerative diseases, such as cardiovascular disease, cancer, and diabetes, as they are closely related to oxidative stress produced by free radicals in the body (11). This has led many studies to focus on natural products that can contribute to the prevention and reduce the risk of suffering from diseases that are difficult to treat. Therefore, the objective of this study was to evaluate the antioxidant capacity and determine the total content of phenols and flavonoids from extracts obtained from the leaves of Ilex guayusa.

\section{MATERIALS AND METHODS}

\section{Plant material}

The plant samples, $5 \mathrm{~kg}$ of I. guayusa fresh leaves, were collected in "Mogambo Sendero Ambiental", located in Viotá, Cundinamarca, Tequendama province, $90 \mathrm{~km}$ from Bogotá; 1310 m.a.s.l, and $20.5^{\circ} \mathrm{C}$ annual average temperature. It is a rain forest ecosystem located at the mountain foot, under the plus code (zip code) CG78+OW. Voucher number 30173 Herbarium of Pontificia Universidad Javeriana. 


\section{Extracts preparation}

One kilogram of I. guayusa fresh leaves, dehydrated at room temperature, went through cold maceration with ethanol at $96 \%$ for 30 days to obtain the total ethanolic extract (TEE). Alternatively, $1 \mathrm{~kg}$ of leaves, dehydrated at room temperature, was extracted by soxhlet method for a week with increasing polarity solvents, initially with dichloromethane (ED), then ethyl acetate (EA), and finally ethanol (EE) to obtain increasing low-mid, mid-high, and high polarity extracts, respectively. The extracts were concentrated at reduced pressure in an IKA HB10 rotary evaporator and were dry stored in a refrigerator at $4^{\circ} \mathrm{C}$. Based on obtained extracts, solutions were prepared at a 1,000-ppm concentration in methanol for antioxidant tests.

\section{DPPH` Scavenging Capacity Assay}

The antioxidant capacity of the extracts obtained from I. guayusa was evaluated by scavenging capacity of the radical DPPH ${ }^{\bullet}(2,2$-diphenyl-1picrilhydrazil), analytical grade, Sigma-Aldrich) according to Brand-Williams et al. (12) method with some modifications. $990 \mu \mathrm{L}$ of a methanolic solution of $\operatorname{DPPH}^{\bullet}(0.1 \mathrm{mM})$ was mixed with $10 \mu \mathrm{L}$ of the extracts at 40 to $200 \mathrm{ppm}$. The mixtures were kept at room temperature and in the darkness for $30 \mathrm{~min}$. Afterward, the absorbance at $520 \mathrm{~nm}$ was measured in a spectrophotometer (Spectronic 21D, Milton Roy). Antioxidant capacity was quantified using ascorbic acid, Trolox, and Rutin calibration curves. Methanol was used as a negative control. Each measure had three replicates. The antioxidant capacity of extracts was calculated as $I=[(A B-$ $A A) / A B] \times 100$, where $I$ is $\mathrm{DPPH}^{\bullet}$ inhibition (\%); $A B$ is the absorbance of a blank sample, and $A A$ is the absorption of the extract solution.

\section{ABTS $^{*+}$ Scavenging Capacity Assay}

It was carried out by the method proposed by Miller et al. (2) with some modifications. The radical was generated by an oxidation reaction of ABTS $^{\cdot+}$ ((2,2-azinobis-(3-ethylbenzthiazoline-6-sulfonic acid)) with potassium persulfate $\left(\mathrm{K}_{2} \mathrm{~S}_{2} \mathrm{O}_{8}\right)$. The extracts were evaluated in a concentration range of 40 to $200 \mathrm{ppm}$, of which $20 \mu \mathrm{L}$ were taken and mixed with $980 \mu \mathrm{L}$ of the $\mathrm{ABTS}^{\bullet+}$ solution previously prepared in a phosphate buffer solution at a $\mathrm{pH}$ of 7.4. The obtained solutions were incubated in the dark at room temperature for $30 \mathrm{~min}$. Subsequently their absorbances at $734 \mathrm{~nm}$ were measured in a spectrophotometer (Spectronic 21D, Milton Roy).
An ascorbic acid, Trolox, and Rutin calibration curve were used. Methanol was used as a negative control. Each measure had three replicates. The percentage inhibition of ABTS ${ }^{\bullet+}$ of the test samples was calculated according to the following formula: $\%$ inhibition $=[(A B-A A) / A B] \times 100$, where $A B$ is the absorbance of a blank sample, and $A A$ is the absorbance of the test sample.

\section{Quantification of total phenols}

The modified Folin-Ciocalteu $(13,14)$ method was used for total phenols quantification. $100 \mu \mathrm{L}$ of the extracts solution $(5 \mathrm{mg} / \mathrm{mL})$ were added to $200 \mu \mathrm{L}$ of the Folin-Ciocalteu reagent (diluted 1:10) in semi-micro PMMA cells. After three minutes, $750 \mu \mathrm{L}$ of $\mathrm{Na}_{2} \mathrm{CO}_{3}$ (7.35\%) were added and allowed to react in the dark for 2 hours (determined by reaction kinetics). After the incubation, the absorbance at 735 $\mathrm{nm}$ was measured in a Thermo Scientific Evolution 605 Spectrophotometer. Each measurement was performed in duplicate. Content of total phenols was determined by interpolating the absorbance in a calibration curve previously constructed using gallic acid as a standard; the result is presented in mg Eq of Gallic Acid /g of Dry Extract (15).

\section{Quantification of total flavonoids}

Total flavonoid content was determined by the Aluminum chloride $\left(\mathrm{AlCl}_{3}\right)$ modified method (16). In borosilicate tubes, $250 \mu \mathrm{L}$ of the extracts' solution were mixed with $375 \mu \mathrm{L}$ of $\mathrm{AlCl}_{3}(10 \%$ in hydroalcoholic solution), $375 \mu \mathrm{L}$ of $0.1 \mathrm{M}$ Sodium Acetate, and 2,000 $\mu \mathrm{L}$ of ethanol (96\%). The mix was allowed to react in the dark for 40 minutes (determined by reaction kinetics). After the incubation, the absorbance at $424 \mathrm{~nm}$ was measured in a Thermo Scientific Evolution 605 Spectrophotometer using the previous mixture as a blank but replacing the $250 \mu \mathrm{L}$ of the sample with ethanol (96\%). Each of the determinations was carried out in triplicate.

\section{Statistical analysis}

The results were expressed in \% radical scavenging activity. The dose-response curves were constructed applying a non-linear regression, and inhibitory concentrations $50\left(\mathrm{IC}_{50}\right)$ in ppm were calculated. The values of the obtained tests were expressed as the mean \pm SEM. Data were analyzed using one-way ANOVA and Tukey's post-hoc. Significant differences were considered for $p<0.05$. The 
statistical program GraphPad Prism version 9.0 for Windows (GraphPad Software, San Diego, California USA, www.graphpad.com) was used.

\section{RESULTS}

The antioxidant capacity was obtained by capturing the free radicals $\mathrm{DPPH}^{\bullet}$ and $\mathrm{ABTS}^{\bullet+}$ using calibration curves of Ascorbic Acid, Trolox, and Rutin (4 to 20 ppm). Of the four extracts, the ethanolic extract (EE) presented inhibition percentages greater than $80 \%$ by the $\mathrm{DPPH}^{\bullet}$ and $\mathrm{ABTS}^{\bullet+}$ methods, respectively (Table 1). Considering that each method has different reaction conditions, it was possible to infer that the extracts contained various compounds with antioxidant capacity. The obtained results showed that, for all the extracts, the values obtained by ABTS $^{\circ+}$ were greater than DPPH ${ }^{\circ}$. This could be explained by the ABTS ${ }^{\bullet+}$ low selectivity since it reacts with any hydroxylated aromatic compound, regardless of its real antioxidant potential. It is important to note that $\mathrm{DPPH}^{\bullet}$ becomes more selective than $\mathrm{ABTS}^{\circ+}$, and unlike the latter, it does not react with flavonoids that do not have hydroxyl groups on the $B$ ring or with aromatic acids that have only one hydroxyl group (17). This could explain the lower values in the $\mathrm{DPPH}^{\circ}$ method compared to the $\mathrm{ABTS}^{*+}$ method.

Table 1. Antioxidant capacity by DPPH and $A B T S^{\circ+}$ (\% radical scavenging activity).

\begin{tabular}{|c|c|c|c|c|}
\hline \multicolumn{5}{|c|}{ DPPHªssay } \\
\hline Concentration (ppm) & $\begin{array}{l}\text { Dichloromethane extract } \\
\text { (ED) }\end{array}$ & $\begin{array}{l}\text { Ethyl acetate extract } \\
\text { (EA) }\end{array}$ & $\begin{array}{l}\text { Total ethanolic extract } \\
\text { (TEE) }\end{array}$ & $\begin{array}{l}\text { Ethanolic } \\
\text { extract (EE) }\end{array}$ \\
\hline 40.00 & $16.92 \pm 0.08$ & $36.02 \pm 0.16$ & $50.86 \pm 0.16$ & $67.05 \pm 0.22$ \\
\hline 60.00 & $20.30 \pm 0.09$ & $44.18 \pm 0.16$ & $71.28 \pm 0.22$ & $83.10 \pm 0.27$ \\
\hline 80.00 & $23.58 \pm 0.10$ & $56.58 \pm 0.19$ & $82.67 \pm 0.26$ & $84.60 \pm 0.29$ \\
\hline 100.00 & $27.03 \pm 0.11$ & $66.18 \pm 0.22$ & $83.54 \pm 0.27$ & $85.84 \pm 0.29$ \\
\hline 120.00 & $30.31 \pm 0.12$ & $71.09 \pm 0.23$ & $84.16 \pm 0.27$ & $86.45 \pm 0.29$ \\
\hline 140.00 & $31.53 \pm 0.12$ & $76.34 \pm 0.25$ & $84.94 \pm 0.27$ & $87.45 \pm 0.30$ \\
\hline 160.00 & $35.35 \pm 0.13$ & $80.54 \pm 0.27$ & $86.17 \pm 0.27$ & $88.03 \pm 0.30$ \\
\hline 180.00 & $38.05 \pm 0.14$ & $81.10 \pm 0.27$ & $86.87 \pm 0.28$ & $88.53 \pm 0.30$ \\
\hline 200.00 & $42.08 \pm 0.17$ & $81.63 \pm 0.27$ & $87.53 \pm 0.28$ & $88.91 \pm 0.30$ \\
\hline \multicolumn{5}{|c|}{ ABTS $^{*+}$ assay } \\
\hline 40.00 & $29.43 \pm 0.10$ & $51.50 \pm 0.16$ & $69.77 \pm 0.18$ & $79.27 \pm 0.22$ \\
\hline 60.00 & $37.65 \pm 0.14$ & $66.09 \pm 0.21$ & $81.60 \pm 0.22$ & $83.71 \pm 0.23$ \\
\hline 80.00 & $42.16 \pm 0.14$ & $73.21 \pm 0.23$ & $86.92 \pm 0.24$ & $90.38 \pm 0.25$ \\
\hline 100.00 & $47.63 \pm 0.16$ & $76.46 \pm 0.24$ & $90.74 \pm 0.26$ & $93.14 \pm 0.25$ \\
\hline 120.00 & $53.29 \pm 0.18$ & $80.83 \pm 0.26$ & $93.40 \pm 0.27$ & $95.14 \pm 0.26$ \\
\hline 140.00 & $60.21 \pm 0.20$ & $82.99 \pm 0.27$ & $95.57 \pm 0.28$ & $96.55 \pm 0.26$ \\
\hline 160.00 & $66.13 \pm 0.22$ & $85.87 \pm 0.28$ & $97.03 \pm 0.28$ & $97.85 \pm 0.27$ \\
\hline 180.00 & $71.22 \pm 0.23$ & $88.91 \pm 0.29$ & $98.23 \pm 0.29$ & $98.41 \pm 0.27$ \\
\hline 200.00 & $79.28 \pm 0.26$ & $91.84 \pm 0.30$ & $98.85 \pm 0.29$ & $99.11 \pm 0.27$ \\
\hline
\end{tabular}

Table 2 shows the $\mathrm{IC}_{50}$ values expressed in $\mathrm{ppm}$. It was observed that the ethanolic extract (EE) showed lower $\mathrm{IC}_{50}$ values (4.58 and $3.82 \mathrm{ppm}$, higher antioxidant capacity) for the $\mathrm{DPPH}^{\bullet}$ and $\mathrm{ABTS}{ }^{\bullet+}$ method, respectively. 
Table 2. $I C_{50}$ calculated values by $D^{\circ P H} H^{\bullet}$ and $A B T S^{++}$

\begin{tabular}{|c|c|c|c|c|}
\hline \multicolumn{5}{|c|}{ DPPH• assay } \\
\hline \multirow{2}{*}{ Extract and patterns } & $\begin{array}{l}\text { Electron captation } \\
\text { index } 50 \mathrm{DPPH}^{\circ}\end{array}$ & $\begin{array}{c}\text { Antioxidant activity related } \\
\text { to Ascorbic acid }\end{array}$ & $\begin{array}{l}\text { Antioxidant activity } \\
\text { related to Rutin }\end{array}$ & $\begin{array}{l}\text { Antioxidant activity } \\
\text { related to Trolox }\end{array}$ \\
\hline & $I_{50}$ & AAR $^{\text {a }}$ Ascorbic Acid & AAR $^{\text {a Rutin }}$ & AAR ${ }^{a}$ Trolox \\
\hline ED & 414.96 & 789.99 & 45.10 & - \\
\hline EA & 64.18 & 122.20 & 7.00 & - \\
\hline EE & 4.58 & 8.70 & 0.50 & - \\
\hline TEE & 23.58 & 44.90 & 2.60 & - \\
\hline Ascorbic acid & 0.52 & 1.00 & 0.10 & - \\
\hline Rutin & 9.20 & 17.50 & 1.00 & - \\
\hline Trolox & - & - & - & - \\
\hline \multicolumn{5}{|c|}{ ABTS $^{++}$assay } \\
\hline \multirow[t]{2}{*}{ Extract and patterns } & $\begin{array}{l}\text { Electron captation } \\
\text { index } 50 \mathrm{ABTS}^{+}\end{array}$ & $\begin{array}{l}\text { Antioxidant activity related } \\
\text { to Ascorbic Acid }\end{array}$ & $\begin{array}{l}\text { Antioxidant activity } \\
\text { related to Rutin }\end{array}$ & $\begin{array}{l}\text { Antioxidant activity } \\
\text { related to Trolox }\end{array}$ \\
\hline & $\mathrm{IC}_{50}$ & AAR $^{a}$ Ascorbic Acid & AAR $^{\text {a Rutin }}$ & AAR ${ }^{\mathrm{a}}$ Trolox \\
\hline ED & 93.35 & 183.90 & 13.50 & 114.50 \\
\hline EA & 32.89 & 64.80 & 4.70 & 40.30 \\
\hline $\mathrm{EE}$ & 3.82 & 7.50 & 0.60 & 4.70 \\
\hline TEE & 10.66 & 21.00 & 1.50 & 13.10 \\
\hline Ascorbic acid & 0.50 & 1.00 & 0.10 & 0.60 \\
\hline Rutin & 6.93 & 0.10 & 1.00 & 8.50 \\
\hline Trolox & 0.81 & 1.60 & 0.10 & 1.00 \\
\hline
\end{tabular}

The ethanolic extracts (high polarity) did not show significant differences with respect to the positive controls (Rutin and Ascorbic Acid), by the $\mathrm{DPPH}^{\bullet}$ method, according to the statistical analysis (ANOVA, posthoc Tukey; mean difference: TEE vs. Rutin $=6.6$ ( $p=0.1039) ;$ TEE vs. Ascorbic acid $=3.3$ $(p=0.7282)$; EE vs. Rutin = $4.94(p=0.3342)$; SE vs. Ascorbic Acid $=4.96(p=0.3295))$. A similar behavior was found by the ABTS ${ }^{\bullet+}$ method (mean difference:
TEE vs. Rutin $=3.2(p=0.4084)$; TEE vs. Ascorbic Acid $=10.19$ ( $p<0.0001$, significant); EE vs. Rutin = $3.55(p=0.3243)$; EE vs. Ascorbic acid = 3.33 ( $p=$ 0.3971), except for TEE compared to ascorbic acid the mean differences with respect to Trolox were significant $(p<0.0001)$. Alternatively, it is important to highlight that the ethanolic extract (EE) showed a lower $I_{50}$ value than the Rutin, by the two methods evaluated (Figure 1). 

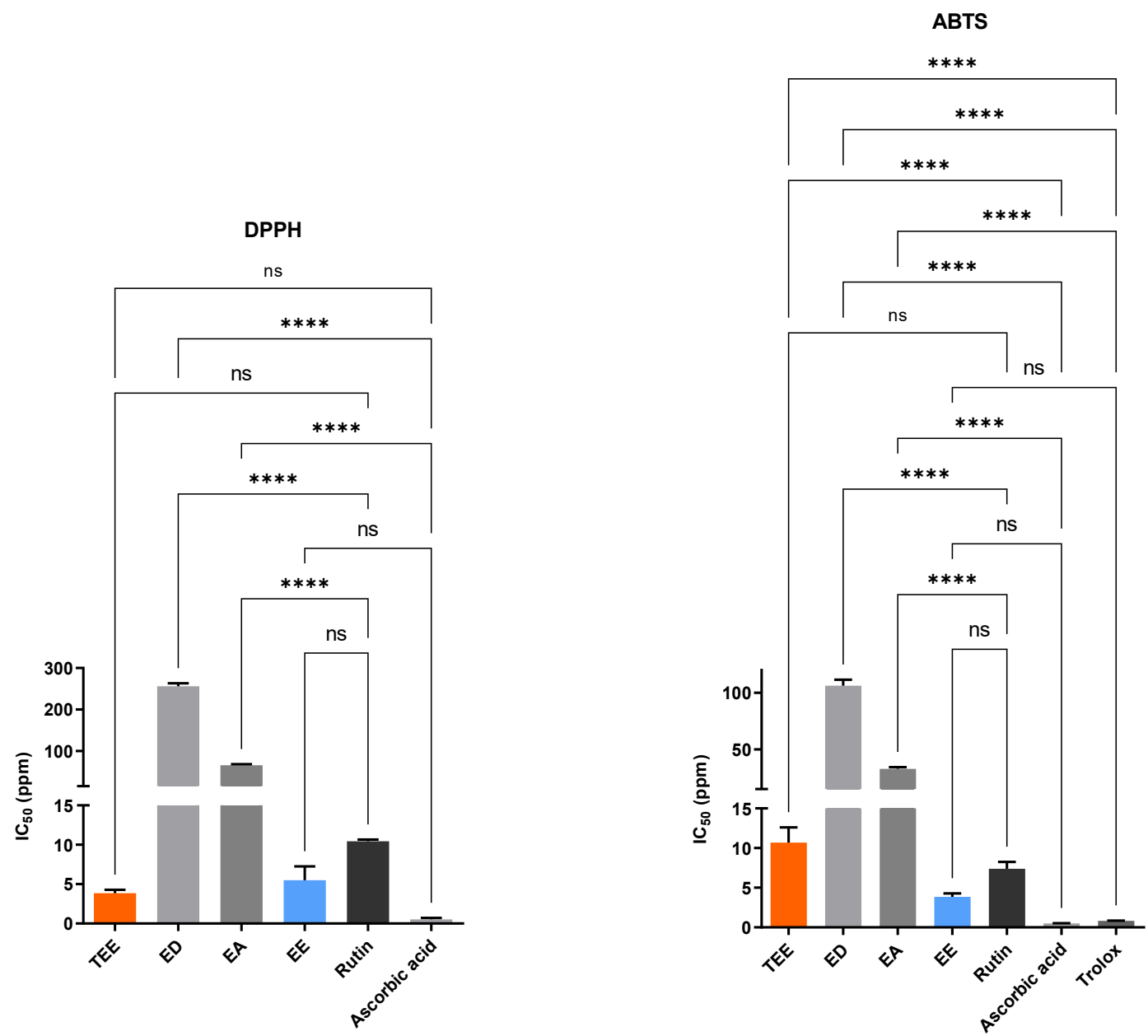

Figure 1. Antioxidant activity - $I C_{50}$ values for the I. guayusa extracts. Ns-not significant

**** $p<0,0001$ (one way ANOVA, post-hoc Tukey).

The values obtained from the quantification of phenols and flavonoids are shown in Table 4. The content of total phenols and flavonoids in plant extracts becomes an important parameter that will establish their antioxidant potential. The FolinCiocalteau and $\mathrm{AlCl}_{3}$ complex formation methods permit quantifying the total content of phenolic and flavonoid compounds, respectively, and are used to analyze plant species and foodstuffs (18). The results obtained showed that EA presented the highest levels of phenols, $508.38 \pm 1.02 \mathrm{mg}$ Eq of Gallic Acid/g sample, while the flavonoid content for this extract was the lowest of all (16.72 \pm 0.32 mg Eq Quercetin/g sample). EE showed a value for phenol content of $357.64 \pm 0.60 \mathrm{mg} \mathrm{Eq}$ of Gallic Acid/g sample and the highest level of flavonoid content (90.13 $\pm 5.81 \mathrm{mg}$ Eq Quercetin/g sample).
Table 4. Total phenols and flavonoids content in extracts of $I$. guayusa.

\begin{tabular}{ccc}
\hline Sample & $\begin{array}{c}\text { Total Phenols Content }^{\text {a }} \\
\text { × SEM }\end{array}$ & $\begin{array}{c}\text { Total Flavonoids Content }^{\mathbf{b}} \\
\mathbf{\pm} \text { SEM }\end{array}$ \\
\hline TEE & $388.38 \pm 0.43$ & $30.43 \pm 0.87$ \\
ED & $198.37 \pm 0.15$ & $76.58 \pm 3.23$ \\
EA & $508.38 \pm 1.02$ & $16.72 \pm 0.32$ \\
EE & $357.64 \pm 0.60$ & $90.13 \pm 5.81$ \\
\hline
\end{tabular}

${ }^{\mathrm{a}} \mathrm{mg}$ Eq of Gallic Acid/g sample, ${ }^{\mathrm{b}} \mathrm{mg}$ Eq Quercetin/g sample

\section{DISCUSSION}

Many studies have highlighted the antioxidant capacity of polyphenols (7). The antioxidant capacity of I. guayusa leaves was evaluated 
by electron transfer-based methods such as $\mathrm{DPPH}^{\bullet}$ and $\mathrm{ABTS}^{\bullet+}$. Jara et al. (2013) evaluated the antioxidant capacity of guayusa by $\mathrm{DPPH}^{\bullet}$ assay to scavenge free radicals and determine the polyphenol composition. They concluded that the antioxidant capacity of I. guayusa ethanolic extracts showed a higher content of phenols and flavonoids, and a higher antioxidant activity (19). These results are comparable with the obtained in this study by the $\mathrm{DPPH}^{\bullet}$ method, with the lowest $I C_{50}$ values reported by the ethanolic extract (EE). Although the ethyl acetate extract presented the highest phenol content, its antioxidant capacity was lower than the ethanolic extract, which may be related to the lower flavonoid content.

The chemistry of phenols has generated great interest in recent years, considering that these compounds are essential, have diverse applications, are antioxidants, and inhibit the oxidative degradation of organic matter, including many aerobic biological organisms (19). Phenolic compounds, being weak acids, act as hydrogen atom donors, capable of reacting with $\mathrm{O} 2 \cdot$ through different mechanisms, depending on their nature and the number of substituents of the phenolic ring, which is why phenols are easily oxidized and act as antioxidants. According to García-Ruíz et al. (2017), I. guayusa reported glycosides flavonols like Quercetin-3O-hexose, kaempferol-3-O-hexose and quercetin 3-O-rutinoside (7). Likewise, flavonoids present specific characteristics for their free radical scavenging activity, including hydroxyl groups at the $\mathrm{C}-5$ positions and the conjugated double bond at C-2 and C-3 with an oxo function at C-4, and also the two hydroxyl groups of the B-ring (20).

Based on ethnobotanical observations of guayusa, recent analytical and phytochemical investigations have provided information on its nutritional content and chemical composition (21). Phytochemical analyses have identified and quantified secondary metabolites of different types, which have been evaluated using different chromatographic methodologies (HPLC-PDA-MS). García-Ruiz et al. 2017 reported concentrations of carotenoids and phenolic compounds for green leaves (7). Villacís-Chiriboga et al. (2018) compare metabolites between young ( 2 months) and mature (6 months) leaves (8). Both studies identified and quantified phenolic compounds within hydroxycinnamic acids and flavonols such as quercetin-3-O-hexose and rutin. These results suggest that the high antioxidant capacity observed in ethanolic extracts of guayusa (EE) could be attributed mainly to the presence of polyphenols.

\section{CONCLUSIONS}

According to the results obtained in this study, it was possible to corroborate that the ethanolic extract (EE) obtained from the I. guayusa leaves showed the highest antioxidant capacity by the DPPH ${ }^{*}$ and ABTS $^{\circ+}$ methods. Additionally, it was possible to relate this capacity to the high flavonoids content present in this extract. Based on the above and future studies, the llex guayusa species could be proposed as an important source of antioxidant compounds with possible application in medicine and the food industry.

\section{CONFLICTS OF INTEREST}

None of the investigators showed any conflict of interest. This investigation was not conducted on human beings nor animals, and does not involve a risk for society, therefore there are no ethical considerations.

\section{AUTHORS' CONTRIBUTIONS}

Jenny Carolina Castañeda Villate, Mayerly Johanna Hernández Roa, and Camila Florenza Cárdenas Tavera participated in the structuring of the study, discussion of the results, and final writing of the manuscript. Oscar Eduardo Rodríguez Aguirre carried out the experimental part and participated in the discussion. Paola Borrego-Muñoz and Luis Miguel Pombo Ospina participated in the conception of the study, experimental phase, discussion of the results, and final writing of the manuscript.

\section{REFERENCES}

1. Lewis WH, Kennelly EJ, Bass GN, Wedner HJ, Elvin-Lewis MP, Fast D. Ritualistic use of the holly llex guayusa by Amazonian Jivaro Indians. J Ethnopharmacol .1991;33:25-30.

2. Arteaga-Crespo Y, Radice M, Bravo-Sanchez LR, García-Quintana Y, Scalvenzi L. Optimisation of ultrasound-assisted extraction of phenolic antioxidants from Ilex guayusa Loes. leaves using response surface methodology. Heliyon .2020;6:0-7. https://doi. org/10.1016/j.heliyon.2019.e03043.

3. Schultes RE. Fifteen years of study of psychoactive snuffs of south america: 1967-1982- a review*. J Ethnopharmacol .1984;11:17-32.

4. Dickau R, Redwood SD, Cooke RG. A 4,000-year-old shaman's stone cache at Casita de Piedra, western Panama. Archaeol 
Anthropol Sci .2013;5:331-49. https://doi.org/10.1007/s12520012-0112-5.

5. Cadena-Carrera S, Tramontin DP, Bella Cruz A, Bella Cruz RC, Müller JM, Hense H. Biological activity of extracts from guayusa leaves (Ilex guayusa Loes.) obtained by supercritical CO2 and ethanol as cosolvent. J Supercrit Fluids .2019;152:104543. https:// doi.org/10.1016/j.supflu.2019.104543.

6. Chóez-Guaranda I, Viteri-Espinoza R, Barragán-Lucas A, Manzano $P$, Viteri-Espinoza R, Barragán-Lucas A. Effect of solvent-solvent partition on antioxidant activity and GC-MS profile of llex guayusa Loes . leaves extract and fractions. Nat Prod Res .2021;Feb 4:1-5. https://doi.org/10.1080/14786419.2021.1882455.

7. García-Ruiz A, Baenas N, Benítez-Gonzáñez AM, Stinco C, Meléndez-Martínez A, Moreno D, et al. Guayusa (llex guayusa L.) new tea: phenolic and carotenoid composition and antioxidant capacity. J Sci Food Agric .2017;97:3929-36. https://doi. org/10.1002/jsfa.8255.

8. Villacís-Chiriboga J, García-Ruiz A, Baenas N, Moreno DA Meléndez-Nartínez A, Stinco C, et al. Changes in phytochemical composition, bioactivity and in vitro digestibility of Guayusa leaves (llex guayusa Loes.) in different ripening stages. J Sci Food Agric .2018;98:1927-34. https://doi.org/10.1002/jsfa.8675.

9. Pardau MD, Pereira ASP, Serem JC, Bester MJ. Antioxidant and anti-inflammatory properties of Ilex guayusa tea preparations: a comparison to Camellia sinensis teas. Food Funct .2019;8:460110. https://doi.org/10.1039/c7fo01067b.

10. Fahmy NM, Al-Sayed E, El-Shazly M, Singab AN. Comprehensive review on flavonoids biological activities of Erythrina plant species. Ind Crops Prod .2018;123:500-38. https://doi. org/10.1016/j.indcrop.2018.06.028.

11. Janabi AHW, Kamboh AA, Saeed M, Xiaoyu L, BiBi J, Majeed F, et al. Flavonoid-rich foods (FRF): A promising nutraceutical approach against lifespan-shortening diseases. Iran J Basic Med Sci .2020;23:140-53. https://doi.org/10.22038/ IJBMS.2019.35125.8353.
12. Brand-Williams W, Cuvelier ME, Berset $C$. Use of a free radical method to evaluate antioxidant activity. LWT - Food Sci Technol .1995;28:25-30. https://doi.org/10.1016/S0023-6438(95)80008-5.

13. Folin $\mathrm{O}$, Ciocalteau V. Tyrosine and Tryptophane in Proteins. J Biol Chem .1927;73:627-48.

14. Ainsworth EA, Gillespie KM. Estimation of total phenolic content and other oxidation substrates in plant tissues using Folin-Ciocalteu reagent. Nat Protoc .2007;2:875-7. https://doi. org/10.1038/nprot.2007.102.

15. Wolfe K, Wu X, Liu RH. Antioxidant activity of apple peels. J Agric Food Chem .2003;51:609-14. https://doi.org/10.1021/jf020782a.

16. Pękal A, Pyrzynska K. Evaluation of Aluminium Complexation Reaction for Flavonoid Content Assay. Food Anal Methods .2014;7:1776-82. https://doi.org/10.1007/s12161-014-9814-х.

17. Palomino, Lady, García C, Gil J, Rojano B, Durango D. Determination of phenolic content and evaluation of actioxidant activity of propolis from Antioquia (Colombia). Vitae, Rev La Fac Química Farm .2009;16:388-95.

18. Marquele FD, Di Mambro VM, Georgetti SR, Casagrande R, Valim YML, Fonseca MJ V. Assessment of the antioxidant activities of Brazilian extracts of propolis alone and in topical pharmaceutical formulations. J Pharm Biomed Anal .2005;39:455-62. https://doi. org/10.1016/j.jpba.2005.04.004.

19. Jara A, Rodriguez Y, Cornejo J, Cazar M, Gutierrez M, Astudillo L. Antioxidant activity and total phenolics of plants used in traditional medicine in Ecuador, .2013, p. 1-6. https://doi. org/10.3390/ecsoc-17-b001.

20. Pietta PG. Flavonoids as Antioxidants. J Nat Prod .2000;63:103542. https://doi.org/10.1021/np9904509.

21. Wise G, Negrin A. A critical review of the composition and history of safe use of guayusa: a stimulant and antioxidant novel food. Crit Rev Food Sci Nutr .2019;60:2393-404. https://doi.org/10.1 080/10408398.2019.1643286. 
Supplementary material. Linear regressions.

DPPH

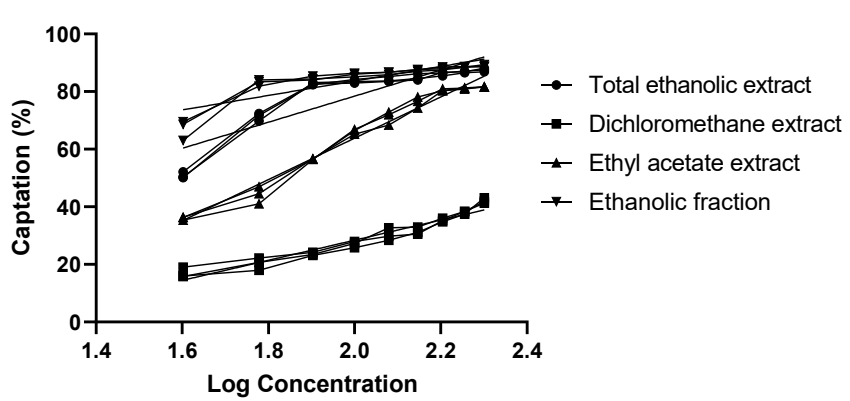

Positive controls (Rutin) ABTS

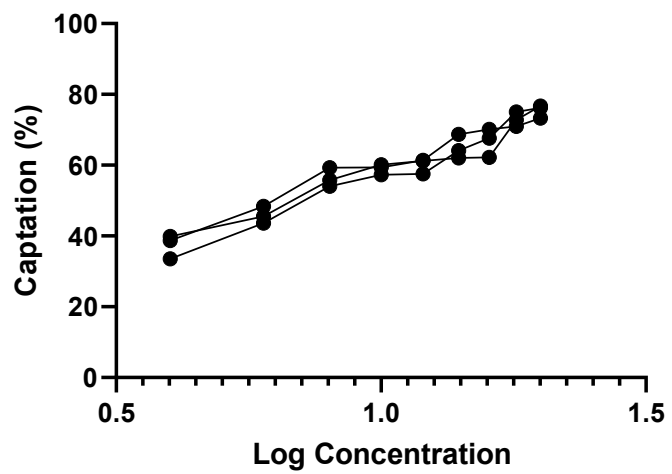

ABTS

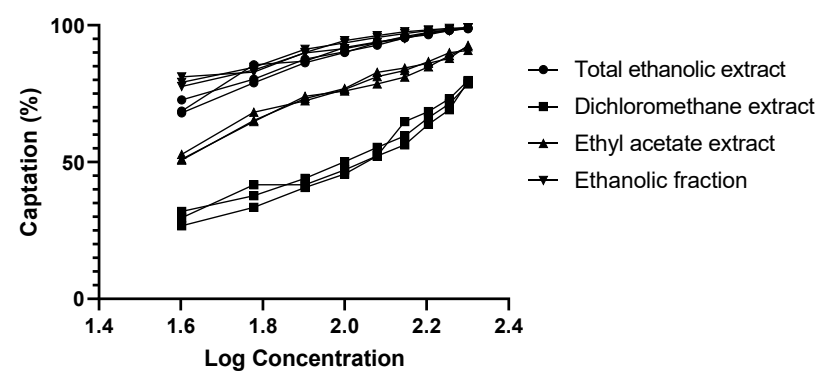

Positive controls (Ascorbic acid, Trolox) ABTS

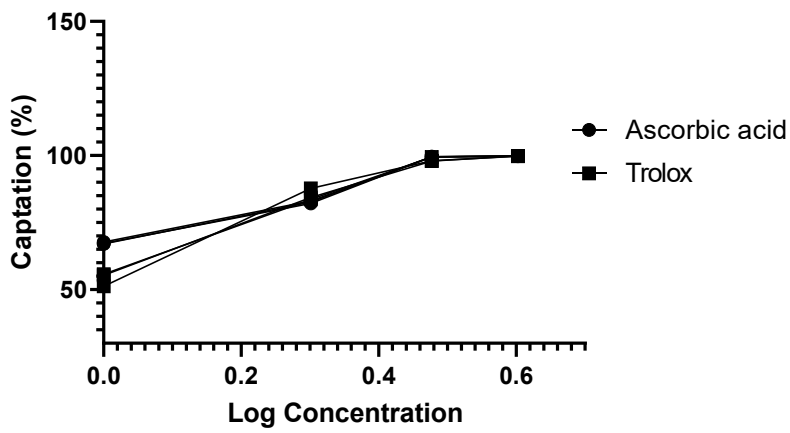

Positive controls (DPPH)

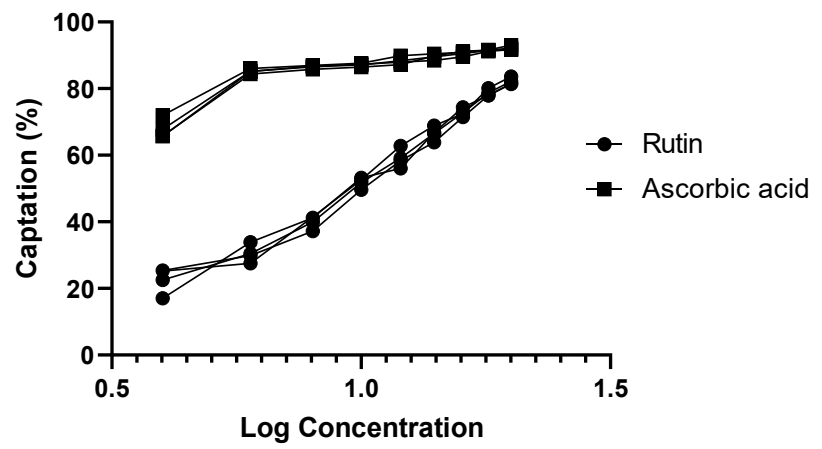




\section{DPPH}

\section{5\% Confidence Intervals (Tukey)}

Ascorbic acid - Ethanolic extract-

Rutin - Ethanolic extract-

Ascorbic acid - Ethyl acetate extract-

Rutin - Ethyl acetate extract

Ethanolic extract - Ethyl acetate extract-

Ascorbic acid - Dichloromethane extract-

Rutin - Dichloromethane extract-

Ethanolic extract - Dichloromethane extract-

Ethyl acetate extract - Dichloromethane extract-

Ascorbic acid - Total ethanolic extractRutin - Total ethanolic extract-

Ethanolic extract - Total ethanolic extract-

Ethyl acetate extract - Total ethanolic extract

Dichloromethane extract - Total ethanolic extract-

$$
-400
$$

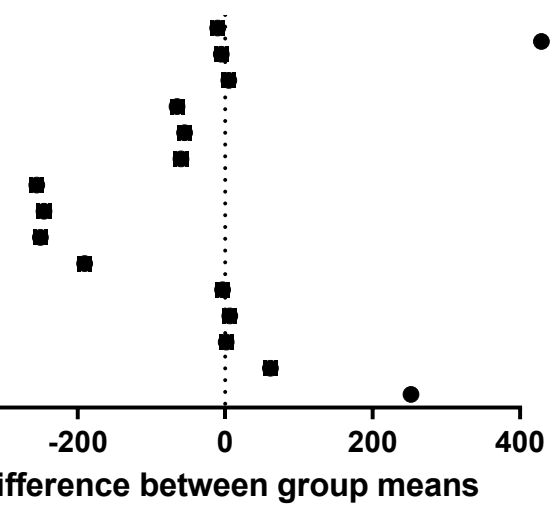

- Column means diff.

ABTS

\section{5\% Confidence Intervals (Tukey)}

Trolox - Ascorbic acid-

Ascorbic acid - Rutin-

Ascorbic acid - Ethanolic extract-

Trolox - Ethyl acetate extract-

Rutin - Ethyl acetate extract-

Trolox - Dichloromethane extract-

Rutin - Dichloromethane extract-

Ethyl acetate extract - Dichloromethane extract-

Ascorbic acid - Total ethanolic extract-

Ethanolic extract - Total ethanolic extract-

Dichloromethane extract - Total ethanolic extract-

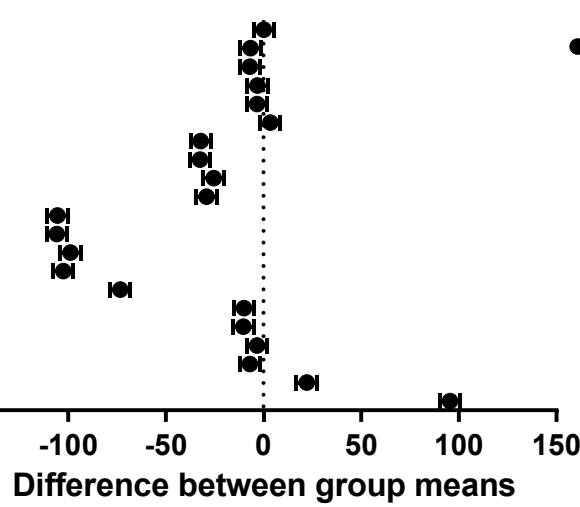

- Column means diff. 